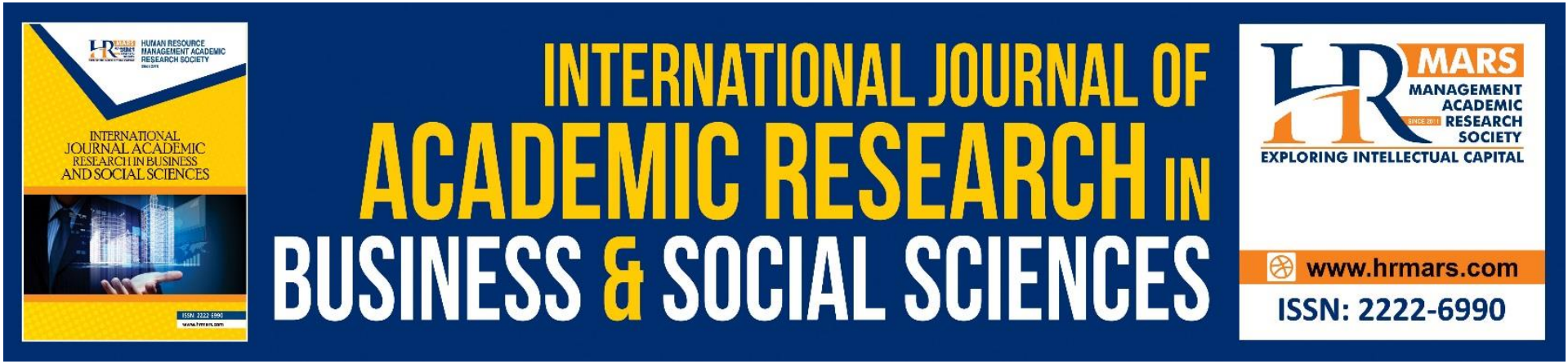

\title{
The Effects of Shopping Mall Attributes on Experience Quality and Engagement Behaviour: Does Gender Matter?
}

Janiffa Saidon, Rosidah Musa, Nuryusmawati Mohd Yusuf and Shamsul Baharin Saihani

To Link this Article: http://dx.doi.org/10.6007/IJARBSS/v11-i9/11255

DOI:10.6007/IJARBSS/v11-i9/11255

Received: 18 July 2021, Revised: 22 August 2021, Accepted: 10 September 2021

Published Online: 26 September 2021

In-Text Citation: (Saidon et al., 2021)

To Cite this Article: Saidon, J., Musa, R., Yusuf, N. M., \& Saihani, S. B. (2021). The Effects of Shopping Mall Attributes on Experience Quality and Engagement Behaviour: Does Gender Matter? International Journal of Academic Research in Business and Social Sciences, 11(9), 1819-1831.

Copyright: @ 2021 The Author(s)

Published by Human Resource Management Academic Research Society (www.hrmars.com)

This article is published under the Creative Commons Attribution (CC BY 4.0) license. Anyone may reproduce, distribute, translate and create derivative works of this article (for both commercial and non-commercial purposes), subject to full attribution to the original publication and authors. The full terms of this license may be seen at: http://creativecommons.org/licences/by/4.0/legalcode

Vol. 11, No. 9, 2021, Pg. 1819 - 1831

Full Terms \& Conditions of access and use can be found at http://hrmars.com/index.php/pages/detail/publication-ethics 


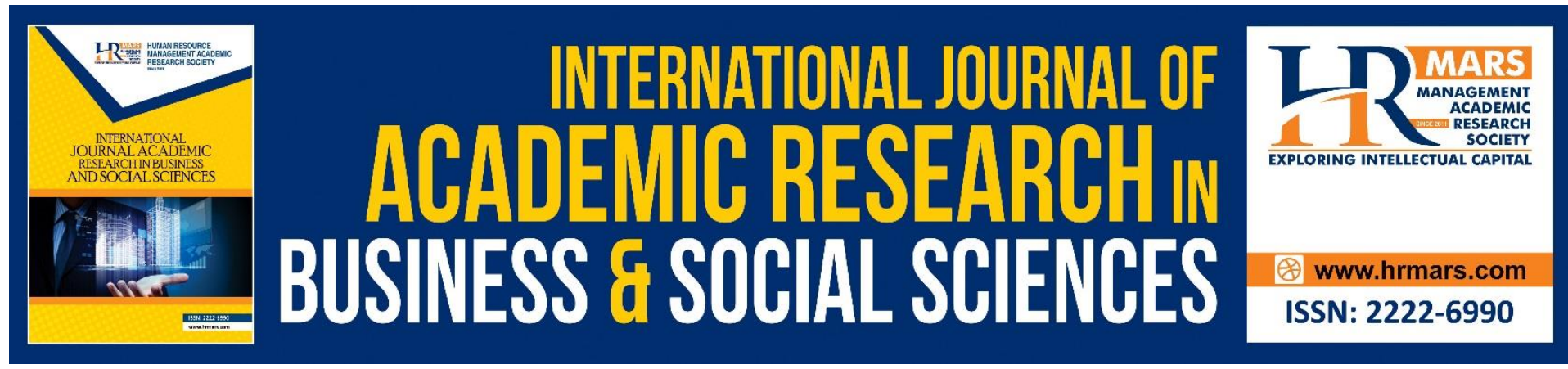

\title{
The Effects of Shopping Mall Attributes on Experience Quality and Engagement Behaviour: Does Gender Matter?
}

\author{
Janiffa Saidon ${ }^{1}$, Rosidah Musa ${ }^{2}$, Nuryusmawati Mohd Yusuf ${ }^{3}$ \\ and Shamsul Baharin Saihani ${ }^{4}$ \\ ${ }^{1}$ Department of International Business, Faculty of Business and Management, Universiti \\ Teknologi Mara, Malaysia, ${ }^{2}$ Institute of Business Excellence, Faculty of Business and \\ Management, Universiti Teknologi Mara, Malaysia, ${ }^{3}$ Department of International Business, \\ Faculty of Business and Management, Universiti Teknologi Mara, Malaysia, ${ }^{4}$ Institute of \\ Business Excellence, Faculty of Business and Management, Universiti Teknologi Mara, \\ Malaysia
}

Email: saidonjb@gmail.com,dr.rosidahmusa@gmail.com,33myresearch@gmail.com, shams887@gmail.com

\begin{abstract}
Over the last decade, the mushrooming of new shopping malls in Klang Valley has compelled mall management to develop strategies that aim to elevate themselves above their competitors. As a result, shopping malls developers and management have deliberately introduced distinctive and unique attributes to act as a magnet to entice and fascinate the shoppers. Comprehensive insights into the customer demographics, trends, and lifestyles will enable mall managers to develop marketing strategies that appeal to potential customers within the catchment area. Despite the emphasis, little research has addressed which attributes are significantly vital in influencing the mall's patrons Experience Quality and Engagement Behaviour. The objective of this study is to unravel the predictors of Experience Quality and, in turn, determine its effect on Engagement Behaviour. Subsequently, this research attempt to investigate empirically whether the shopping mall patron's profile, in this case, gender, will moderate the hypothesized relationships between constructs in the research model. The research model was developed based on the SOR (Stimulus-Organism Response) Model. The research hypotheses were tested and validated with 181 shopping mall visitors obtained through shopping mall interception at five shopping malls in Klang Valley, Malaysia, in 2018. The multi-group analysis using SmartPLS software was conducted to determine the moderating effect of gender on hypothesized links among constructs in the research model. The results imply that mall Atmospherics and Entertainment and Event are predictors of Experience Quality for the male patrons. Whilst the mall Atmospherics is the only significant predictor of Experience Quality for female patrons. Additionally, the result exemplifies a significant positive effect of Experience Quality on Engagement Behaviour for male and female mall patrons. Research implications, limitations and future research directions are discussed and advocated.
\end{abstract}


Keywords: Shopping Mall, Experience Quality, Mall Atmospherics, Engagement Behaviour.

\section{Introduction}

A physical shopping mall as one of the retailing formats, also known as brick and mortar, has become increasingly remarkable, despite intensifying competition from the online store (David et al., 2018). Nowadays, shopping malls have become more than just a place to shop; the mall culture plays a significant role in consumers' lifestyles. Backstorm in 2011 asserted that consumers demand the shopping mall to be their recreational getaway. They wanted to enjoy the company of other people by having social interaction with family members or friends. Therefore, the shopping malls are struggling to satisfy their customers' needs to retain their customers and encourage them to revisit the shopping mall. Despite this emphasis, little research had been carried out to examine factors that influence shopping mall experience quality, which then influences the engagement behaviour among the shopping mall patrons. Most prior research focused on the mall patrons' satisfaction; however, the consequences of the shopping mall experience quality formed by the different gender remain unclear (Tan and Ooi, 2018). More importantly, the patron's shopping mall experience quality is crucial in influencing their engagement with the shopping mall. If this urgency is not addressed, the customers will patronize other shopping malls or adopt the online store. So, in order for the shopping mall to sustain itself and be profitable, the shopping mall must be able to pull the crowd (Borgers and Vosters, 2011). Prior literature has linked the consequences of customer experience with engagement behaviour, such as revisiting the shopping mall, advocating or recommending the mall to others. The emerging trend of engagement behaviour is sharing location, pictures, and video via social media.

It was reported that young shoppers aged $18-24$ years old are the most challenging customers, with $23 \%$ more likely to face problems than other shoppers. These younger shoppers are the active shoppers. They spent $25 \%$ more time in the mall compared to shoppers over 40 years old group. Furthermore, they visit $70 \%$ more stores during a shopping mall visit. In the same report, for mall shopping, men have $16 \%$ more negative experiences than women. However, women talk more about the problems they have. $33 \%$ will discuss their shopping mall problems with friends or colleagues compared to less than $25 \%$ of men (Verde Group Report, 2019). The millennials cohort predominantly depends on the product description to evaluate the quality of the material and artistry (Musa et al., 2020), and they are always connected to the internet. It is important to note that Paula Courtney, the CEO of the Verde Group, claimed that by 2020, customer experience would be taking over price and product as the key influencing factor, and that was not surprised as it was also reported from the Gartner Survey in $2019,81 \%$ of the companies will be competing mainly or entirely based on customer experience. Now in 2021, retailers in the shopping mall are struggling to sustain their business operation physically and have to operate them online due to the Covid' 19 crisis.

Regardless of the continuous promotion towards online shopping and the decreasing traffic flow to the shopping mall due to the movement restriction orders of Covid'19, society still yearns to visit the physical store. Surveys have been done, and it is found that $72.6 \%$ of respondents are willing to follow the standard of operating procedure (SOP) as long as they get to visit and shops at the physical store. As such, determining factors that influence the shopping mall experience is crucial. 
In essence, it is deemed critical to gain insights into the shopping mall attributes in predicting experience quality and customer engagement behaviour. These critical insights are anticipated to lead to the success and sustainability of the shopping mall (Amin et al., 2020). Thus, the main objective of this research was to unravel the predictors of experience quality in the context of shopping malls and subsequently delve into the consequence of the experience quality, specifically on patron's engagement behaviour. Subsequently, the research aims to determine the magnitude of influence of gender on all the proposed hypothesized linkages in the structural model.

\section{Literature Review}

The research model is depicted in Figure 1. The development model was based on the S-O-R (Stimuli - Organism - Response) Model, adopted from the environmental psychology research stream (Russell, 1980). In the current study, the stimuli are operationalised as shopping mall attributes or characteristics: Convenience and Accessibility, Facilities, Entertainment and Event, Atmospherics and Tenant Mix. These five stimuli were selected since they are common attributes and services offer by most shopping malls and bolstered by previous literature (Kim and Kim, 2008; Dennis et al., 2010; Borgers and Vosters, 2011; El-Adly and Eid, 2017; Lee and Choi, 2019). The model's organism component comprises seven emotions: satisfaction, inspiring, interesting, delight, enjoyable, memorable and lively. The response component comprises consumers' intentions to revisit the shopping mall, recommend the shopping mall to others and share pictures, videos, and locations using social media platforms.

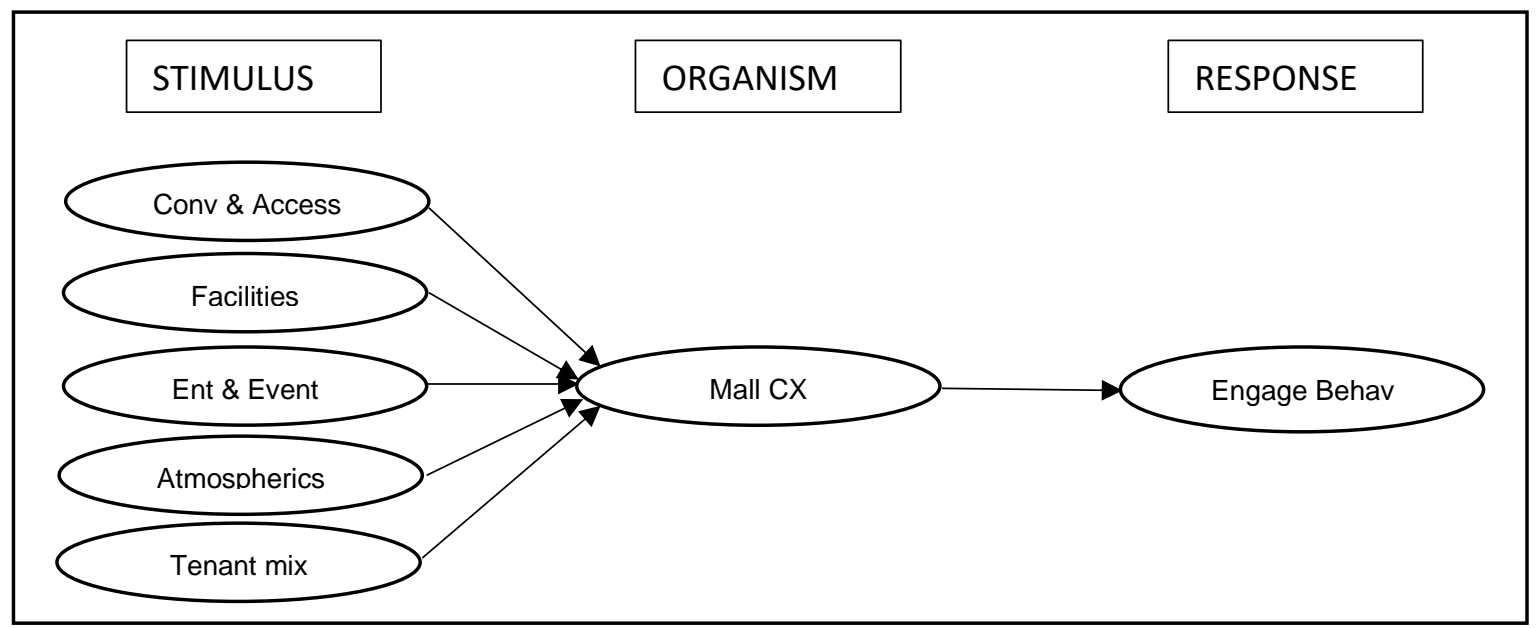

Fig. 1: Research Framework

Convenience in the shopping mall landscape can be defined as the mall's capability to reduce the time and effort spent during the purchasing process (El-Adly and Eid, 2017). According to El Hedhli in his research in 2013, convenience is one of the utmost significant keys in attracting consumers to patronage a shopping mall. This concept existed way back in 2009 where Clulow and Reimers mentioned that one-stop shopping, locations, enclosed environment and extended business hours are factors that could be offered to customers to ease them. This idea was further supported by research done in 2019, which claimed that developing a shopping mall with attractive, convenient, and pleasant features was strategically effective (Lee and Choi, 2019). Indeed, it was observed most that most shopping malls offered ample parking facilities and convenient business hours and located themselves in a prime area where 
it is easy to reach. As a result, those shopping malls located in highly accessible areas were expected to be perceived more favorably. They patronized more than those shopping malls located in less accessible areas. Altukar and Kesari, in 2017, found that if the customers perceive the mall is convenient, it will strongly influence their level of satisfaction towards the shopping mall.

Shopping malls are progressively becoming a place where society meets up even though they do not intend to shop. Many shoppers considered shopping as the most enjoyable leisure activity. Nevertheless, patronizing a shopping mall has been widely considered a leisure-time enjoyment activity beyond functional utility (Kim and Kim, 2008). More specifically, hedonic shopping values are recognized through entertainment and the event that the shopping malls provide. Entertainment facilities such as events, music, food courts and refreshment outlets will create pleasure and enjoyment during the shopping process (Altukar and Kesari, 2017). Few researchers agreed that most retailers believed that the shopping mall's layout and the merchandise's presentation significantly influence the shoppers' enjoyment experience (Adapa et al., 2020; Jang et al., 2018).

The shopping mall atmosphere plays a crucial role in attracting customers to stay longer and revisit the mall in the future (Dennis et al., 2010). Das and Varshneya also support this in 2017, they claimed that the shopping malls environment is divided into five main categories: the layout, human variables, interior, exterior, and how the product is displayed. All these were believed to affect the time spent in the shopping mall and the intentions to repatronage. Likewise, the internal environment is projected to form an emotional response and influence the mall's overall evaluation (Correia-Loureiro and Roschk, 2014). As a result, features related to style, aesthetics, image and appearance are deemed relevant in influencing the shopping mall patrons' attraction.

The tenant mix or tenant variety is referred to as the existence of various retail stores in the shopping mall. According to El-Adly and Eid in 2017, shopping malls that carry various types of retail stores in its building have a high potential to pull the crowds. This is simply because customers are looking at the shopping malls to get the most value of the products they are searching for or known as a one-stop center. Nevertheless, customers would also love to make product comparisons (Damian et al., 2011). On the order hand, it is reported that $60 \%$ of men are bothered by too many retail stores carrying the same product (The Verde Group Report, 2019). There is an adequate indication that tenant variation in malls may influence the shoppers' behavioral responses (Borgers and Vosters, 2011).

It is strongly believed that customers' with positive mall experiences will engage with positive behaviour. They may re-patronage the shopping mall, share their experience through social media, recommend the shopping malls to family members and friends and nevertheless may lead to purchase intention. Verhoef et al. (2009) describe the experience involving "cognitive, affective, social and physical responses to the retailer". Grewal et al. (2009) focus purely on behavioural outcomes such as retention, cross-buying and word-of-mouth.

In order to remain competitive in the shopping industry, the shopping mall experience quality and behavioral intentions need to play a crucial role in retaining the long-term relationship between the shoppers and the shopping malls (Jin et al., 2020). 
This research attempt to test the eight hypotheses proposed as follows:

$\mathrm{H} 1$ : Convenience and Accessibility has a positive effect on Experience Quality

H2: Facilities has a positive effect on Experience Quality

H3: Entertainment and Event has a positive effect on Experience Quality

H4: Atmospheric has a positive effect on Experience Quality

H5: Tenant Mix has a positive effect on Experience Quality

H6: Experience Quality has a positive influence on the shopping mall patrons' Engagement Behaviour

H7: The magnitude of the influence of the shopping mall attributes (Convenience and Accessibility, Facilities, Entertainment and Event, Atmospherics and Tenant Mix) on Mall Experience Quality will be moderated by gender

H8: The magnitude of the influence of Experience Quality on Engagement Behaviour will be moderated by gender

\section{Methodology}

\section{Data Collection and Research Instrument}

Three hundred fifty patrons of six selected shopping malls in Klang Valley, Malaysia, were asked to fill up the structured questionnaires to collect information concerning their shopping mall experience. After considering the suspicious response patterns and missing values, only 181 sets of the survey are considered valid. The distribution of gender and age are as listed in Tables 1 and 2.

\section{Data Analysis}

The researchers had utilized the SmartPLS software in order to examine the research model. Utilizing the two-stage analytical procedures Andersen and Gerbing (1988) introduced, the researchers conducted the measurement and structural models. SmartPLS 3.2.7 was used to perform the data analysis. Preceding to that, Statistical Package for Social Sciences (SPSS) version 22 was used for data coding, cleaning and generating the result for descriptive analysis. Lastly, a Multigroup analysis was performed to analyse the path differences between the two groups (male and female shopping mall patrons).

\section{Empirical Results}

Demographics: The average age of the patrons in the study is between 21-30 years old (69.1\%). In this research, the descriptive analysis result shows that the gender distribution was about balance, female, 99 and male, 82.

Table 1: Gender Distribution

\begin{tabular}{lll}
\hline Gender & Frequency & $\%$ \\
\hline Male & 82 & 45.3 \\
Female & 99 & 54.7 \\
\hline Total & 181 & 100.0 \\
\hline
\end{tabular}


Table 2: Age Distribution

\begin{tabular}{lll}
\hline Gender & Frequency & $\%$ \\
\hline $17-20$ & 32 & 17.7 \\
$21-30$ & 125 & 69.1 \\
$31-40$ & 19 & 10.5 \\
$41-50$ & 5 & 2.8 \\
\hline Total & 181 & 100.0 \\
\hline
\end{tabular}

\section{Measurement Model}

\section{Convergent Validity}

Analysis of the measurement model was conducted to confirm the reliability and validity of the items used. Hair et al., (2017) advised to consider factor loadings, composite reliability (CR) and average variance extracted (AVE) in assessing the convergent validity. For the factor loadings, the recommended value is above 0.5 (Hair et al., 2017). The factor loadings result was between the ranges of 0.649 to 0.930 , while the CR varies from 0.829 to 0.905 . The AVE for shopping mall experience was found to be 0.614 that is the lowest value among other constructs in the model but higher than the minimum cut-off value of 0.5 (Hair et al., 2017). Hence, all the items and factors are considered to be reliable and were summarized in Table 3.

Table 3: Result of Measurement Model

\begin{tabular}{|c|c|c|c|c|}
\hline Constructs & Items & $\begin{array}{l}\text { Factor } \\
\text { Loadings }\end{array}$ & $\begin{array}{l}\text { Composite } \\
\text { Reliability (CR) }\end{array}$ & $\begin{array}{l}\text { Average } \\
\text { Variance } \\
\text { Extracted } \\
\text { (AVE) }\end{array}$ \\
\hline \multirow[t]{5}{*}{$\begin{array}{ll}\text { Convenience } & \text { and } \\
\text { Accessibility } & \\
\end{array}$} & $\mathrm{IM} 1$ & 0.785 & 0.897 & 0.636 \\
\hline & IM2 & 0.786 & & \\
\hline & IM3 & 0.780 & & \\
\hline & IM4 & 0.786 & & \\
\hline & IM5 & 0.850 & & \\
\hline \multirow[t]{3}{*}{ Facilities } & IM6 & 0.803 & 0.829 & 0.622 \\
\hline & IM7 & 0.649 & & \\
\hline & IM8 & 0.894 & & \\
\hline \multirow[t]{3}{*}{$\begin{array}{ll}\text { Entertainment and } \\
\text { Event }\end{array}$} & IM10 & 0.753 & 0.851 & 0.656 \\
\hline & IM11 & 0.855 & & \\
\hline & IM12 & 0.819 & & \\
\hline \multirow[t]{4}{*}{ Atmospheric } & IM14 & 0.816 & 0.891 & 0.672 \\
\hline & IM15 & 0.884 & & \\
\hline & IM16 & 0.841 & & \\
\hline & IM17 & 0.730 & & \\
\hline \multirow[t]{4}{*}{ Tenant Mix } & IM18 & 0.669 & 0.902 & 0.701 \\
\hline & IM19 & 0.876 & & \\
\hline & IM20 & 0.910 & & \\
\hline & $1 \mathrm{M} 21$ & 0.871 & & \\
\hline
\end{tabular}




\begin{tabular}{|l|l|l|l|l|}
\hline & & & & $\begin{array}{l}\text { Average } \\
\text { Variance } \\
\text { Extracted } \\
\text { (AVE) }\end{array}$ \\
\hline Constructs & Items & $\begin{array}{l}\text { Factor } \\
\text { Loadings }\end{array}$ & $\begin{array}{l}\text { Composite } \\
\text { Reliability (CR) }\end{array}$ & 0.614 \\
\hline & TX1 & 0.749 & 0.905 & \\
\hline & TX2 & 0.798 & & \\
\hline & TX3 & 0.796 & & \\
\hline & TX4 & 0.770 & & \\
\hline & TX5 & 0.824 & & \\
\hline $\begin{array}{l}\text { Engagement } \\
\text { Behaviour }\end{array}$ & TX6 & 0.762 & & 0.746 \\
\hline & LE1 & 0.859 & 0.898 & \\
\hline & LE2 & 0.930 & & \\
\hline & LE3 & 0.798 & & \\
\hline
\end{tabular}

\section{Discriminant Validity}

There are few methods to test the discriminant validity. Since there was no issue in reliability where the factor loadings and composite reliability value were all very good and according to Cheung et al. (2010), discriminant validity is a matter of distinguishing among the constructs or measuring the distinct concepts. Therefore researchers opt to use Fornell and Larcker test for the discriminant validity, and the result was summarized in table 4 . The result shows that the square root of the AVE is higher than the correlation values in row and column. Therefore, it can be concluded that the measurement model is accepted as it fits all the criteria of convergent and discriminant validity.

Table 4: Discriminant Validity of Constructs (Fornell \& Larcker)

\begin{tabular}{|c|c|c|c|c|c|c|c|}
\hline & $\begin{array}{l}\text { Atmosphe } \\
\text { ric }\end{array}$ & $\begin{array}{l}\text { Conv. and } \\
\text { Accessibili } \\
\text { ty }\end{array}$ & $\begin{array}{l}\text { Engageme } \\
\mathrm{nt} \\
\text { Behaviour }\end{array}$ & $\begin{array}{l}\text { Entertainm } \\
\text { ent and } \\
\text { Event }\end{array}$ & $\begin{array}{l}\text { Faciliti } \\
\text { es }\end{array}$ & $\begin{array}{l}\text { Mall } \\
\mathrm{CX}\end{array}$ & $\begin{array}{l}\text { Tena } \\
\text { nt } \\
\text { Mix }\end{array}$ \\
\hline $\begin{array}{l}\text { Atmospheri } \\
\mathrm{C}\end{array}$ & 0.820 & & & & & & \\
\hline $\begin{array}{l}\text { Convenienc } \\
\text { e and } \\
\text { Accessibility }\end{array}$ & 0.590 & 0.798 & & & & & \\
\hline $\begin{array}{l}\text { Engagemen } \\
\text { t Behaviour }\end{array}$ & 0.398 & 0.220 & 0.864 & & & & \\
\hline $\begin{array}{l}\text { Entertainm } \\
\text { ent and } \\
\text { Event }\end{array}$ & 0.535 & 0.254 & 0.234 & 0.810 & & & \\
\hline Facilities & 0.547 & 0.765 & 0.301 & 0.323 & 0.789 & & \\
\hline Mall CX & 0.409 & 0.285 & 0.572 & 0.336 & 0.279 & $\begin{array}{l}0.78 \\
4\end{array}$ & \\
\hline Tenant Mix & 0.580 & 0.738 & 0.213 & 0.171 & 0.682 & $\begin{array}{l}0.28 \\
0\end{array}$ & 0.837 \\
\hline
\end{tabular}

Note: Square root of the AVE on the diagonal. 


\section{Structural Model}

Sang et al (2010) added that a structural model indicates the causal relationship among constructs in a model (path coefficient and the $\mathrm{R}^{2}$ value). Both path coefficient (beta and significance) and the $R^{2}$ value explain how the data supports the model's hypothesized causal relationship (Chin, 1998). Figure 2 and figure 3 shows the comparison path model between male and female. While table 5 summarized the structural analysis for both groups, male and female. The structural model results show that $18.6 \%$ of the influencing factors explained the shopping mall experience, while $23.8 \%$ of the shopping mall experience explained the shopping mall patrons' engagement behaviour.

The positive experience of shopping mall patrons will influence higher engagement behaviour in males compared to females. Surprisingly, as demonstrated by the findings, males are influenced by entertainment and events but not females. However, it was unexpected that convenience, facilities and tenant mix were not significant predictors for the shopping mall experience in both groups-these findings perhaps due to the young groups' patrons.

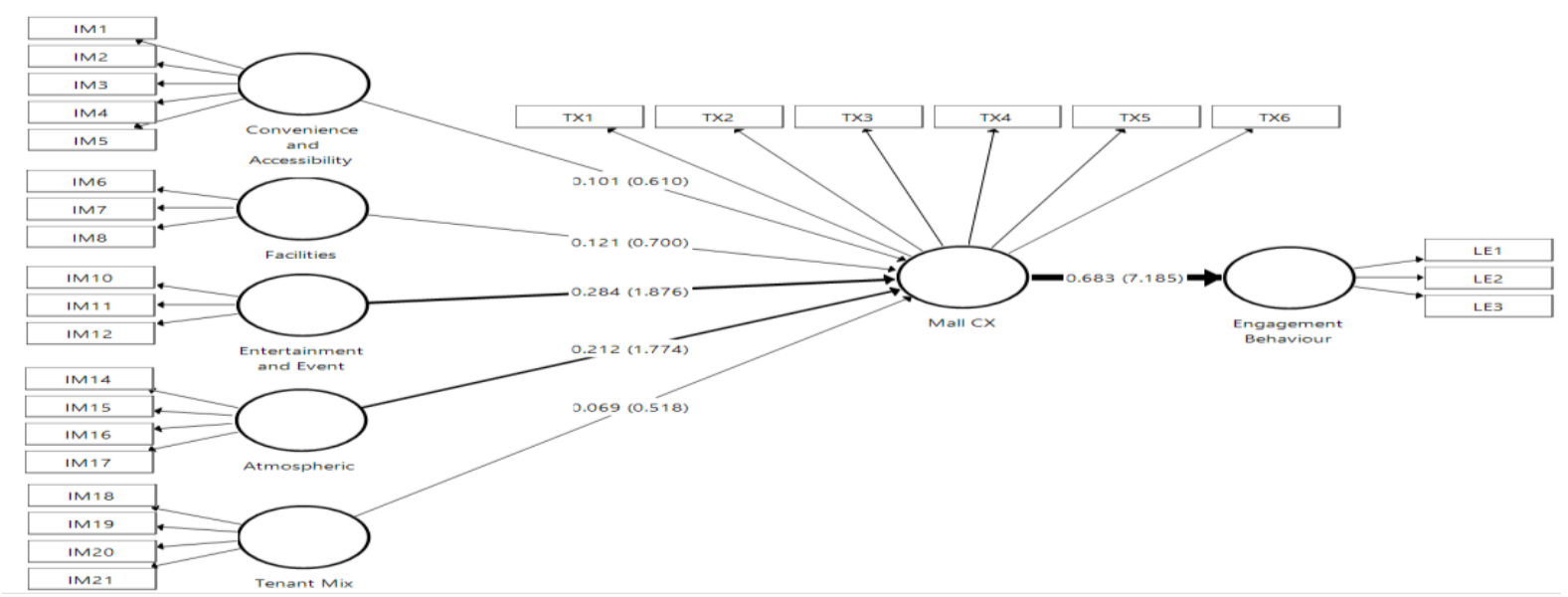

Fig 2: The Structural Model (Male)

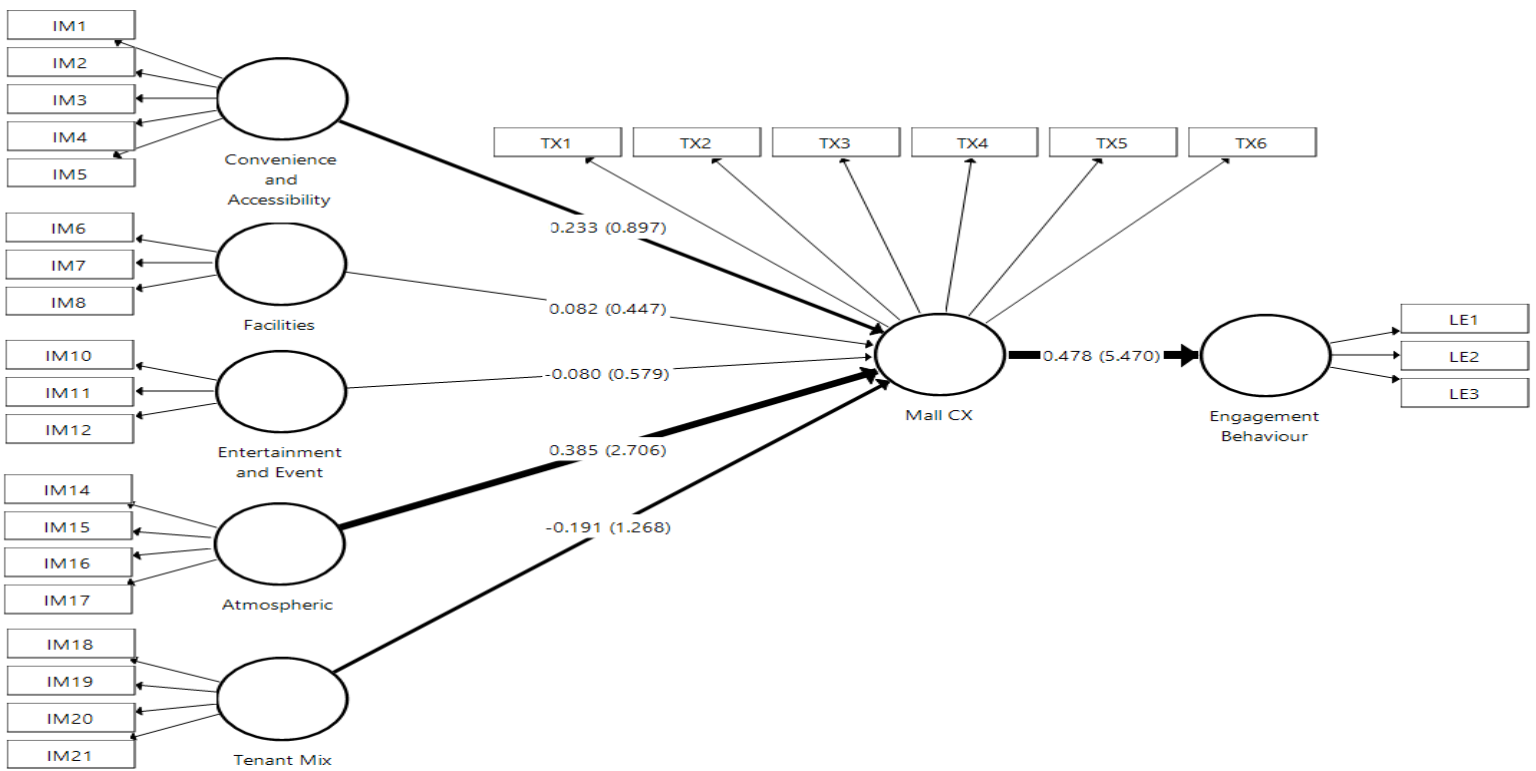

Fig 3: The Structural Model (Female) 
Table 5: Summary of the Structural Model

\begin{tabular}{|c|c|c|c|c|c|c|c|}
\hline \multicolumn{2}{|c|}{ Hypothesis } & $\begin{array}{l}\text { Std } \\
\text { Beta } \\
\text { (MALE } \\
\text { ) }\end{array}$ & $\begin{array}{l}\text { Std Beta } \\
\text { (FEMALE } \\
\text { ) }\end{array}$ & $\begin{array}{l}\text { t- } \\
\text { Value } \\
\text { s } \\
\text { (MALE } \\
\text { ) }\end{array}$ & $\begin{array}{l}\text { t-Values } \\
\text { (FEMALE } \\
\text { ) }\end{array}$ & $f^{2}$ & $\mathrm{R}^{2}$ \\
\hline $\begin{array}{l}\mathrm{H} \\
1\end{array}$ & $\begin{array}{l}\text { Convenience and Accessibility - } \\
>\text { Mall CX }\end{array}$ & 0.101 & 0.233 & 0.610 & 0.897 & 0.04 & \multirow{5}{*}{$\begin{array}{l}0.18 \\
6\end{array}$} \\
\hline $\begin{array}{l}\mathrm{H} \\
2\end{array}$ & Facilities -> Mall CX & 0.121 & 0.082 & 0.700 & 0.447 & 0.00 & \\
\hline $\begin{array}{l}H \\
3\end{array}$ & $\begin{array}{l}\text { Entertainment and Event }-> \\
\text { Mall CX }\end{array}$ & 0.284 & -0.08 & 1.876 & 0.579 & 0.09 & \\
\hline $\begin{array}{l}\mathrm{H} \\
4\end{array}$ & Atmospheric -> Mall CX & 0.212 & 0.385 & 1.774 & 2.706 & 0.05 & \\
\hline $\begin{array}{l}H \\
5\end{array}$ & Tenant Mix -> Mall CX & 0.069 & -0.191 & 0.518 & 1.268 & 0.03 & \\
\hline $\begin{array}{l}\mathrm{H} \\
6\end{array}$ & $\begin{array}{l}\text { Mall CX } \rightarrow \text { Engagement } \\
\text { Behaviour }\end{array}$ & 0.683 & 0.478 & 7.185 & 5.470 & 0.58 & $\begin{array}{l}0.23 \\
8\end{array}$ \\
\hline
\end{tabular}

Note $: p<0.05 \square$ Supported

\section{Conclusion}

In a nutshell, this research was conducted rigorously and perseverance to achieve its objectives and ensure the generated results were reliable and valid. The empirical analysis using SmartPLS yields valuable insights on the crucial predictors and the consequences of the shopping mall experience quality. Additionally, it was unraveled that mall atmospherics and entertainment and events were significant predictors for experience quality for male mall patrons. Surprisingly, entertainment is the only significant predictor for experience quality for female patrons. These findings afford valuable insights for shopping mall management to develop and design shopping malls that create value propositions exclusively targeted to specific demographic profiles. It is anticipated that managing the patrons' experience quality effectively may lead to a great and memorable experience, which is much sought after by customers today.

It is important to note that the shopping mall experience plays a vital role in influencing patrons' engagement behaviour. The research findings imply that shopping mall operators should emphasise their efforts and prioritise their resources to improve the patrons' experience quality towards the shopping mall. The effect of experience quality on engagement behaviour is significant in both groups. However, the influence is more substantial for the male patrons. Undoubtedly, by reinforcing the influencing factors, it is reasonable to expect that the patrons will gradually develop better experiences quality towards the shopping mall, which consecutively will influence their engagement behaviour. This concept is in line with several prior researchers (Atulkar and Kesari, 2017; Gilison and Reynolds, 2018; Maleki and Gholomian, 2020).

This study focuses exclusively on five top shopping malls in Klang Valley, Malaysia, via mall interception. The sample thus could be considered as a convenience sample. Even though 
respondents represented the typical shopping population in Malaysia, but did not they represent shoppers from various generational cohorts. It is important to note that almost $87 \%$ of the respondents in the current study were below 30 years old. In essence majority of the respondents are millennials. It would be interesting for future studies to include more diverse mall patrons aged, particularly 30 to 50 . Therefore, caution should be exercised in interpreting and generalizing the results of shopping malls in other countries and the demographics profiles. Replication studies must be undertaken to validate the findings using different shopping mall environments across other geographical areas and conduct multi-group analysis on other population demographic profiles and generational cohorts. In addition, it will be fertile for future research to extend these findings by focusing on individual-level consumers' cultural orientations effect on their shopping mall experience quality. It is anticipated that the cultural values might be different among the country's residents (Schoefer et al., 2019). Future studies would also be interesting if they were to look for the findings if there are any differences in the shopping mall experience quality among the shoppers from the utilitarian and functional shopping experience (Djelassi et al., 2018; Gilboa et al., 2016).

\section{Acknowledgements}

The Fundamental Research Grant Scheme (FRGS) granted by the Ministry of Higher Education Malaysia and the assistance of Universiti Teknologi MARA are very much appreciated in making this research endeavor a success.

\section{References}

Adapa, S., Fazal-e-Hasan, S. M., Makam, S. B., Azeem, M. M., \& Mortimer, G. (2020). Examining the antecedents and consequences of perceived shopping value through smart retail technology, Journal of Retailing and Consumer Services, 52, 1-11.

Amin, M., Ryu, K., Cobanoglu, C., Rezaei, S., \& Wulan, M. M. (2020). Examining the effect of shopping mall attributes in predicting tourist shopping satisfaction and behavioral intentions: Variation across generation $X$ and $Y$, Journal of Quality Assurance in Hospitality \& Tourism, $1-28$.

Anderson, J. C., \& Gerbing, D. W. (1988). Structural Equation Modelling in Practice: A Review and Recommended Two -Step Approach, Psychological Bulletin, 103(3), 411 - 423.

Atulkar, S., \& Kesari, B. (2017). Satisfaction, loyalty and repatronage intentions: Role of hedonic shopping values, Journal of Retailing and Consumer Services, 39(11), 23-34.

Backstorm, K. (2011). Shopping as leisure: An exploration of manifoldness and dynamics in consumers shopping experiences, Journal of Retailing and Consumer Services, 18(3), $200-209$.

Borgers, A., \& Vosters, C. (2011). Assessing preferences for mega shopping centers: A conjoint measurement approach, Journal of Retailing and Consumer Services, 18(4), $322-332$.

Cheung, C. M. K., \& Lee, M. K. O. (2010). A theoretical model of intentional social action in online social networks, Decision support systems, 49(1), $24-30$.

Chin, W. W. (1998). The Partial Least Squares Approach to Structural Equation Modeling. In Modern Methods For Business Research, edited by G.A Marcoulides. London: Lawrence Erlbaum Associates, pp: 295 -336.

Clulow, V., \& Reimers, V. (2009). Retail centers: It's time to make them convenient, International Journal of Retail and Distribution Management, 37(7), $541-562$. 
Correia-Loureiro, S. M., \& Roschk, H. (2014). Differential effects of atmospheric cues on emotions and loyalty intentions with respect to age under online/offline environment, Journal of Retailing and Consumer Services, 21(2), $211-219$.

Damian, D. S., Dias-Curto, J., \& Castro-Pinto, J. (2011). The impact of anchor stores on the performance of shopping centers: The case of sonae sierra, International Journal of Retail and Distribution Management, 39(6), 456 - 475.

Das, G., \& Varshneya, G. (2017). Consumer emotions: Determinants and outcomes in a shopping mall, Journal of Retailing and Consumer Services, 38, 177-185.

David, J. F., Mangold, W. G., Raju, P. S., \& Valsalan, S. (2018). The mobile shopping revolution: Redefining the consumer decision process, Business Horizons, 61, 323-338.

Dennis, C., Newman, A., Michon, R., Brakus, J., \& Wright, L. (2010). The mediating effects of perception and emotion: digital signage in mall atmospherics, Journal of Retailing and Consumer Services, 17(3), $205-215$.

Djelassi, S., Godefroit-Winkel, D., \& Diallo, M.F. (2018). Does culture affect the relationships among utilitarian and non-utilitarian values, satisfaction and loyalty to shopping centres? Evidence from two Maghreb countries, International Journal of Retail and Distribution Management. 46 (11/ 12), 1153-1169.

El Hedhli, K., Chebat, J. C., \& Sirgy, J. M. (2013). Shopping well-being at the mall: constructs, antecedents and consequences, Journal of Business Research, 66(1), $856-863$.

El-Adly, M. I., \& Eid, R. (2017), Dimensions of the perceived value of the malls: Muslim's shoppers perspective, International Journal of Retail and Distribution Management, $45(1), 40-56$.

Grewal, D., Levy, M., \& Kumar, V. (2009). Customer experience management in retailing: an organising framework. Journal of Retailing, 85, 1-14.

Gilboa, S., Vilnai-Yavetz, I., \& Chebat, J. C. (2016). Capturing the multiple facets of mall experience: developing and validating a scale, Journal of Consumer Behavior, 15, 48-59.

Gillison, S. T., \& Reynolds, K. E. (2018). Satisfaction while shopping for another person: How others'product evaluations influence shopper satisfaction, Journal of Marketing Theory and Practice, 26(3), 211-229.

Hair Jr, J. F., Hult, G. T. M., Ringle, C., \& Sarstedt, M. (2017). A Primer on Partial Least Square Structural Equation Modeling (PLS-SEM). London: SAGE Publications, Incorporated.

Jang, J. Y., Baek, E., \& Choo, H. J. (2018). Managing the visual environment of a fashion store: Effects of visual complexity and order on sensation-seeking consumers, International Journal of Retail and Distribution Management, 46(2), 210-226.

Jin, H., Moscardo, G., \& Murphy, L. (2020). Exploring Chinese outbound tourist shopping: A social practice framework, Journal of Travel Research, 59(1), 156-172.

Kim, H., \& Kim, Y. (2008). Shopping enjoyment and store shopping modes: The moderating influence of chronic time pressure, Journal of Retailing and Consumer Services, 15(5), $410-419$.

Lee, J. S., \& Choi, M. (2019). Examining the asymmetric effect of multi-shopping tourism attributes on overall shopping destination satisfaction, Journal of Travel Research, 59(2), 295-314.

Maleki, F., \& Gholamian, A. (2020). Antecedents and consequences of ethnic tourist satisfaction: The moderating role of ethnic identity, Journal of Heritage Tourism, 1-15.

Musa, R., Saidon, J., \& Rais, M. N. (2020). Unlocking the point of interest in muslimah fashion advertisement: Evidence from gaze plot and time to first fixation eye tracker analysis, Malaysian Journal of Consumer and Family Economics, 25(S1), 187 - 200. 
Russell, J. A. (1980). A circumplex model of affect. Journal of Personality and Social Psychology, 39, 1161-1178.

Sang, S., Lee, J. D., \& Lee, J. (2010). E-government adoption in Cambodia: A partial least squares approach, Transforming Government: People, Process and Policy, 4(2), 138 157.

Schoefer, K., Wappling, A., Heirati, N., \& Blut, M. (2019). The moderating effect of cultural value orientations on behavioral responses to dissatisfactory service experiences, Journal of Retailing and Consumer Services, 48, 247-256.

Tan, G. W., \& Ooi, K. (2018). Gender and age: Do they really moderate mobile tourism shopping behavior? Telematics and Informatics, 35(6), 1617-1642.

Verhoef, P., Lemon, K. N., Parasuraman, A., Roggeveen, A., Tsiros, M., \& Schlesinger, L. A. (2009). Customer experience creation: determinants, dynamics and management strategies. Journal of Retailing, 85, 31-41. 